\title{
Capturing the psychological well-being of Chinese factory
} workers

\begin{tabular}{|r|l|}
\hline Journal: & International Journal of Operations and Production Management \\
\hline Manuscript ID & IJOPM-06-2019-0492.R1 \\
\hline Manuscript Type: & Research Paper \\
\hline Keywords: & $\begin{array}{l}\text { Supply chain, Supply chain risk management social sustainability diary } \\
\text { research psychological capital, Social responsibility, psychological capital, } \\
\text { CSR, Diary research }\end{array}$ \\
\hline
\end{tabular}

\section{SCHOLARONE ${ }^{\text {M }}$ Manuscripts}


IJOPM Paper

Title: Capturing the psychological well-being of Chinese factory workers

Authors: Bellingan, Minette ${ }^{1}$; Tilley, Catherine ${ }^{2}$; Batista, Luciano ${ }^{3}$; Kumar, Mukesh ${ }^{1}$; Evans, Steve ${ }^{1}$

${ }^{1}$ Cambridge University, ${ }^{2}$ Kings College London, ${ }^{3}$ Aston Business School

\begin{abstract}
Purpose

Businesses are under pressure to ensure social responsibility in their globalised supply chains. However, conventional factory audits are not providing adequate data about production workers' well-being. Industry attempts to measure working conditions have shown bias and inconsistency and there is no consensus on what to measure, or how. Well-being can be intangible and difficult to capture without appropriate theoretical and methodological frameworks. This paper investigates factors influencing the well-being of a Chinese factory's workers, tests an innovative research method, and proposes interventions to improve well-being in factories.
\end{abstract}

Design/methodology/approach

This is a longitudinal study using the diaries of production workers at a large assembly manufacturing site in China. Workers left daily digital voice diaries about their day, which were analysed to identify factors related to their well-being at work.

Findings

The picture is more complex than the concerned Western narrative suggests.

Workers' personal and professional concerns extend beyond the criteria currently measured in audits, tending to be more relational, and less about their

physical state.

Practical implications

The current approach of auditing management practices neglects workers' well-being. This study offers a more comprehensive view of well-being and tests a new method of investigation.

Originality/value

This is the first study to use diary methods in a Chinese factory. It addresses an issue supported by little empirical evidence. It is the first longitudinal study to hear from factory workers themselves about how they are and what impacts their well-being daily.

\title{
Keywords
}

Supply chain, risk management, social sustainability, diary research, psychological capital, CSR, CSR audit. 


\section{Introduction}

Rapid growth and industrialisation in China are driving a debate about workers' well-being. Since 1990, it has become viable for emerging economies such as China's to integrate into global commodity chains and production networks by supplying multi-national and transnational corporations (Yang and $\mathrm{He}, 2016$ ). China has become known as 'the world's factory' as it supplies much of the textile, electronics and consumer goods industries (Yang and He, 2016). However, this has been accompanied by growing concerns about the welfare of workers. Companies are under pressure to demonstrate that they are behaving in a way that is socially responsible, since businesses suffer both financial and reputational penalties from CSR violations in their supply chains (Locke et al., 2007; Andersen and Skjoett-Larsen, 2009; Cruz, 2013; Görg et al., 2018).

However, there are problems of transparency in global supply chains. It is difficult for businesses to know what is happening in factories. The most common form of self-regulation among global businesses manufacturing in the developing world is social audits conducted by third parties, but these do not provide an understanding of the needs and dissatisfactions of the workers (O'Rourke, 2003; Anner, 2012; Freise and Seuring, 2015; Sanders et al., 2018) as they tend to focus on the visible, physical aspects of a factory rather than taking a more holistic view of worker well-being. Although there is an extensive body of research on workplace well-being in the West (Fisher, 2014) its concepts have not been tested in Chinese factories. The authors therefore identified two research problems: first, identifying the issues that are most important to workers; and second, identifying possible ways to improve their well-being. This study addresses these problems by applying a novel longitudinal approach to understanding employees' satisfaction with their working conditions. Using digital diaries, workers describe daily events in their lives, and their feelings about these, providing qualitative data to be used to identify the issues important to their well-being. This data is analysed using a grounded approach to provide insights not only into individual well-being, but into the way in which this is influenced by relationships with co-workers and factory management and by the broader HR and operational systems of the factory. This provides a more nuanced understanding of the well-being of Chinese factory workers than that available through conventional methods. For example, Western news often describes factory violations in terms which are unrealistic, such as "nightmarish conditions", or vague, such as "mistreating workers" (Taylor, 2018). These articles are frequently framed around CSR responses from major brands, as opposed to the experiences of workers.

An important contribution of the research is the finding that the actual picture is more complex than the concerned Western narrative suggests (Chan, 2001; Jacka, 2014). Despite the importance of the physical environment for workers' well-being (Lamb and Kwok, 2016), this study shows that workers' personal and professional concerns tend to be more aspirational and relational, and less about their physical state, and to extend beyond the criteria currently measured in audits. It corroborates suggestions that psychological factors are of critical importance to workers' well-being (Rivkin et al., 2018). This article argues that companies will need to be more thoughtful and active about investing in worker engagement and understanding the true needs and intrinsic motivations of the 
people who work in their factories. Specifically, the paper sets out to identify the factors workers themselves consider important to their well-being and, by doing so, to develop a model of well-being for Chinese factory workers that incorporates the elements of psychological capital (Luthans and Youssef-Morgan, 2017) that can potentially lead to improved productivity, reputation and staff retention for businesses. The study also applies an innovative method for collecting primary data from workers, which can be used not only to inform new approaches to audit but also to identify interventions that can be implemented to improve well-being.

The article is organised as follows. The next section presents an overview of the current situation for Chinese factory workers and discusses the conflicting narratives undermining a full understanding of their welfare. This is followed by a section presenting the core theoretical basis of well-being from which the study draws. The methodological aspects of the research are then presented, and an innovative method for collecting data about factory workers' experiences described. The next section presents findings and analysis, revealing the main drivers of factory workers' well-being and identifying possible interventions to improve their welfare. The paper concludes by situating these findings in the context of previous research, discussing theoretical and practical implications and proposing directions for further research.

\section{The situation for Chinese workers: two conflicting narratives}

In the past decade, China has surpassed the United States in terms of purchasing power. It has been the world's largest exporter since 2009. Factory work, seen as part of China's movement toward globalised modernity, has created a new Chinese urban working class of more than 200 million migrants (Pun and Lu, 2010; Grayson and Nelson, 2013). Many of these people migrated to improve their situation, citing the potential to take classes and learn skills to increase their employability as a motivation for working in factories (Jacka, 2014). Pun quotes a dagongmei or female migrant worker saying: "Young people nowadays no longer like tilling the fields. I didn't either." (Pun, 2005). For many in China, choosing to work in a factory can be seen as an act of agency, and workers choose to leave unsatisfactory factories and workplaces to find employment elsewhere (Ma and Jacobs, 2010). In addition to promotion opportunities and upward mobility, workers seek opportunities for skills development (Ma and Jacobs, 2010). As Chinese factory work and access to information through technology evolves, workers become increasingly concerned with achieving an urban lifestyle and pursuing opportunities such as securing urban education for their children (Unger and Siu, 2019).

While this sounds positive, there are real concerns about the conditions these factory workers face. These can be social: divide-and-rule tactics by leaders, including hidden bartering systems (Siu, 2017), may undermine the potential social capital of a collectivistic workplace (Earley, 1994). A fierce struggle for upward advancement, for example to be line leaders, results from management practices promoting divisiveness and individualism rather than solidarity, even within a primarily collectivistic culture (Earley, 1994; Jacka, 2014; Siu, 2017). They can also be physical: a lack of regulations has in the past allowed for workplace injuries, illness due to insufficient health care and factory-based 
tragedies such as fires (Pun, 2005). Stories about such incidents in the media pose a reputational risk to brands sourcing from these factories (Glendon, 2013; Rogers, 2016).

Welfare concerns raised in the Chinese and Western media also appear in the academic literature. Scholars have rightly been concerned about workers' safety, labour rights and pay. Articles detailing long hours, low wages, management abuses, inhumane conditions and workplace injuries (Chan, 2013) appeal to urban liberals' concern for social justice, applying moral pressure to advance workers' rights (Chan, 2013; Jacka, 2014). The victimisation of migrant workers, a frequent theme in Chinese tabloids, has entered the Western narrative for similar reasons. While this narrative has inspired research among Western management theorists, it does not provide useful data to inform remote decisionmaking. Portraying the migrant worker as a victim may also perpetuate stereotypes stigmatising the rural population (Jacka, 2014).

Thus, there are two apparently contradictory stereotypes of the Chinese migrant worker: the new member of the rising middle class, and the victim of exploitation. It is difficult to test these two stereotypes because migrant workers have relatively little voice. Other research from developing markets suggests that worker voice has a dual role: first, it allows formal structures for complaint (Zajak, 2017); and second, it can play a role in workplace well-being by allowing workers to exercise and express their agency (Gunawardana, 2014). Unger and Siu (2019) observe that technology such as mobile phones and chat rooms has enabled Chinese migrant workers to improve their ability to share information with each other about working conditions. However, this knowledge is not necessarily reaching brands. Migrant workers may see silence as essential to their survival (An and Bramble, 2017) and the main means by which brands would find out about problems in their supply chain - strike action - is used only as a position of last resort (Chan, 2017; Franceschini, 2020).

Major international brands face a dilemma. They are under pressure to act in a way that is socially responsible, and so need to find ways to understand workers' conditions in the face of the conflicting narratives. However, as supply chains become more complex, it is harder to know what is actually happening across the entire system. The conventional way for a company to address this need to understand the workers in their supply chain is through auditing factory and workplace health and safety. However, these audits have two significant limitations. First, their focus is primarily on physical conditions, to the exclusion of psychological aspects of workers' well-being. Second, audit methods supply data based on observations at a single point in time, whereas well-being is an ongoing state.

One reason for these limitations is that there is no standardised view of what constitutes well-being for a Chinese migrant factory worker. The literature on sustainable supply chain management, particularly following disasters such as Rana Plaza, focuses on labour standards and codes of conduct (Köksal et al., 2017) and on the relationships and interactions between buying organisations and the stakeholders who take measures to hold them accountable for sustainable production and development (Köksal et al., 2017). These frameworks do not incorporate theories from the existing bodies of literature about workers' well-being. 


\section{Theories of well-being}

Despite the importance of well-being for mental and physical health (Diener, 2000), there is little agreement about how it should be defined and measured (Fisher, 2014). At the most fundamental level, the models draw from three distinct views of the drivers of well-being: the hedonic view, which focuses on pleasant experiences in life; the eudaimonic view, which focuses on inner growth and development; and the social view, which focuses on the relational aspects of well-being (Fisher, 2014). These three categories are related, and include a range of indicators that are not necessarily independent and can act in combination (Gallagher et al., 2009). Thus, a variety of constructs are used in different combinations, in different contexts, by different scholars.

These views of well-being have been used in different ways to describe and measure aspects of life at work for nearly a century (Fisher, 2014). Much of the previous work in the area focuses on hedonic aspects of work life - for example, job satisfaction or positive affect at work. Indeed, job satisfaction is the most commonly researched phenomenon in organisational behaviour (Weiss and Brief, 2001; Wright and Nishii, 2006). However, there is an increasing body of literature examining eudaimonic aspects of work. This examines sources of wellbeing such as meaning at work (Pratt and Ashforth, 2003) and has its roots in work on positive psychology. Some eudaimonic phenomena, such as flow (Csikszentmihalyi, 1990) are also hedonically pleasurable, and so concern two different aspects of workplace well-being. In the last two decades there has also been a growth in studies of the social aspects of well-being at work, such as relationships with peers and leaders, and good quality relationships (Dutton, 2003). Figure 1 shows examples of different types of well-being that have been studied in life and in the workplace.

Figure 1: The drivers of well-being as seen in life and work [Insert Figure 1 here]

These descriptions of well-being have led to two distinct paths of research: first, exploring the relationship between well-being and performance; and second, seeking to understand how well-being can be improved.

There is an established body of literature making a connection between workers' psychological well-being and their performance (Luthans et al., 2005; Sein et al., 2010; Newman et al., 2014; Capasso et al., 2018). This evidence suggests that improving some forms of well-being has benefits for the business as well as for the individual worker. Birdi and other scholars saw improved communication between workers and managers leading to autonomy and empowerment, motivating employees to work harder and more flexibly (Hackman and Oldham, 1976; Birdi et al., 2008), encouraging "thinking big" and more "initiative" (Frese et al., 1996; Birdi et al., 2008; Frese, 2008) and practical, hands-on engagement, reducing supervision costs (Frese et al., 1996; Parker et al., 2001; Birdi et al., 2008). Cottini found involving workers in setting work practices led to less attrition, avoiding rehiring costs while allowing workers to gain experience (Cottini et al., 2011). 
Recent studies building on the literature on positive organisational behaviour offer a framework to suggest the individual capabilities needed for psychological well-being. Luthans' (2002) model of psychological capital (PsyCap) identifies four elements - hope, self-efficacy, resilience and optimism - which improve a range of outcomes, including problem-solving (Hsu and Chen, 2015), organisational citizenship behaviour (Qadeer and Jaffery, 2014; Pouramini and Fayyazi, 2015; Nolzen, 2018), and a "mastery-oriented mindset toward training" (Luthans et al., 2011). Even in challenging workplaces, PsyCap and well-being can allow workers to feel less stressed and more resourceful and engaged, enhancing productivity (Siu et al., 2014; Mazzetti et al., 2016; Joo and Lee, 2017). Nel and Kotze (2017) found positive psychological capital, along with psychological tools like mindfulness and meditation, able to alleviate extreme job stresses, reducing levels of burnout.

Unlike many of the concepts and models in the field of workplace well-being, the PsyCap model has been tested in China. Luthans' studies in three Chinese factories are the only examples to date applying the model in manufacturing in the developing world. Two papers, published in 2005 and 2008, use PsyCap in Chinese factories to investigate their workers' well-being, with a specific focus on the relationship between an individual's psychological capital and their work performance. Among workers at three factories, Luthans et al. (2005) found that stimulating positive psychological states significantly boosted performance. However, there are some methodological limitations to this work. To measure PsyCap's correlation with performance, Luthans used surveys completed by supervisors evaluating the workers. Management surveys are particularly fragile to bias and can be manipulated. This is a particular risk in this research setting where poor employee performance may reflect badly on the management.

There is, however, a clear disconnect between these views of well-being and the information available through factory audits. Audits only assess a few aspects of physical, hedonic well-being, such as workstation comfort. This focus on physical well-being is understandable, given that there have been cases where the basic physical conditions of worker safety have not been achieved. However, it is clear that well-being, which has material benefits for both the individual and the employer, is much more complex and multi-dimensional. There is not, as yet, an agreed, standardised model of employee well-being to form a baseline for more comprehensive observations, audits or surveys (Locke, 2013; Vogel, 2010; O'Rourke, 2003). Much of the research to date has been developed and tested in the West, and so may miss important cultural aspects of well-being.

Furthermore, most research has been conducted in contexts where there is a clear delineation between workplace well-being and well-being in life. Chinese migrant workers, by contrast, live alongside their colleagues in factory accommodation, and so this distinction may be less sharply defined for them.

One reason research on well-being to date has neglected Chinese factory workers is that the research setting itself presents particular problems. Factories are noisy and often overcrowded; they do not always allow for transparent or accessible data capture. To truly understand workers' well-being would involve enquiring about personal matters - such as feelings of safety which are difficult to observe or rank, and about which it may be difficult for workers to be honest, given the imbalance of power between observer and 
observed (Chan, 2013; Anner, 2012; Egels-Zandén, 2014). Alternatives like ethnography or covert observation may uncover this information but are difficult and time-consuming. Survey and observation methods also tend to take their measurements at a single point in time, whereas well-being is an ongoing process. Longitudinal data would provide a better understanding of factory conditions (Peterson et al., 2011).

This study set out to identify the factors workers themselves consider important to their well-being by listening to their daily reflections on what makes a good day at work. By doing this, the researchers aimed to develop a model of wellbeing for Chinese migrant factory workers and a method for collecting this data that could be used, first to inform new approaches to audit, and second to identify areas for intervention to improve well-being.

\section{Method}

\subsection{The research context}

Researching employee well-being in a Chinese factory presents very specific methodological problems. This study required qualitative longitudinal data reflecting the factors most important to workers. Factories are challenging environments for worker interviews or observation due to noise, overcrowding and a fear of repercussions if workers are seen talking to researchers about the factory. Many conventional approaches to collecting qualitative data, such as interviews, were judged unsuitable, as an earlier study by the first author had found factory workers reluctant to talk to researchers. In some instances they had been coached on suitable responses by their managers (Egels-Zandén, 2014; Niforou, 2015).

Diary research was selected for this study because longitudinal data, captured close to real time using flexible and accessible methods, was a very good fit with the conditions in factories. Since diary research has not been used before with factory workers in China, a series of deliberate design decisions was required (Snowden, 2015). Our aim was to replicate real diaries, like those documenting the medical histories of patients, "private worlds of politicians and the fictional lives of characters like Adrian Mole and Bridget Jones" (Taylor and Taylor, 2003; Patterson, 2005) to gain a deep understanding of what working in a factory is really like.

The study comprised a 20-day pilot followed by the 100-day study, with monthly meetings with participants to maintain momentum. The 100-day period was chosen so that the study had ended by 30 days before Chinese New Year. In these 30 days factories are typically so busy that the workers would not have had time to participate in the research, and the majority of workers start to leave before the holiday for their hometowns.

\subsection{Data collection}

The data was all collected from workers in a single factory in Guangdong province which makes bags for Western brands. This work is generally safe and does not involve working with toxic materials. The factory is audited regularly and is considered a safe working environment. The programme was advertised in the factory, inviting all workers to volunteer, providing a self-selecting sample of the factory's total worker population. 100 participants signed up on the day 
the research was opened, more than anticipated. Data from past survey research in factories had included responses from 'fake workers' and management, or multiple responses from single workers. Each volunteer was therefore interviewed face-to-face at the factory to validate the sample, ensuring it actually represented the factory's worker population and that participants gave informed consent. The diarists are all migrants. 91\% were working outside their province of origin at the start of the study, with the remaining $9 \%$ from elsewhere in Guangdong. $68 \%$ of the diarists have children (typically living with family members in their place of origin), and 66\% were under the age of 30.

Phones in China are now ubiquitous, especially among migrant workers in South China factories (Ngan and Ma, 2012; Peng and Choi, 2013). As well as maintaining contact with families left behind in hometowns, they may be used as a diary, for collecting contacts, conversations and lifestyle and entertainment information. Since the majority of the factory workers did have mobile phones, an innovative voice-diary method allowing for daily data collection was selected.

Diary methods relying on reading and writing had been judged potentially problematic as some workers are not fully literate and most would be too tired at the end of the working day to write a diary. Participants were therefore invited to leave a daily voice message sharing 'what made them happy today' and 'what made them unhappy today' or anything they wanted to share about their well-being or day. Using voice messages allowed all workers to participate, regardless of their reading and writing ability, and reduced the time spent by the workers on the diaries - leaving a daily voice message takes only seconds. By enabling workers to make entries at any point in their day it also reduced recall bias (Alaszewski, 2006). Workers were asked to keep their diaries even during holidays and days off, both for continuity and in the hope it would become a normal daily ritual, leading to more insightful, open and useful content. For this diary research, the social-media platform WeChat was used. WeChat (Chinese: 微信, literally, 'micro-message') is a Chinese multi-purpose social media mobile application developed by Tencent. Released in 2011, by 2018 it was reported in international media to be one of the largest stand-alone mobile apps by monthly active users, with a billion users ( $83 \%$ of smartphone users) in China, and a further 100 million internationally. It has been called China's 'app for everything' because of its wide range of functions. It is censored and monitored in China. WeChat has several features that made it suitable for this research. It allows communities to be created, information to be posted and voice messages to be left, and has a built-in instant translation tool, so that an English-speaker can chat to someone in Chinese and vice versa. It supports various instant messaging methods, including text and voice messages, walkietalkie and stickers.

Diary entries were downloaded from WeChat daily and saved to Excel. Translation software was used as part of a three-step daily process to convert them into English: using the WeChat translator to produce an initial text, to be checked using Google Translate, then audited by a native speaker. To preserve anonymity, each worker was given a number and an animal name. This way they could chat on the forum and leave their diaries without feeling concerned about confidentiality. Only the first author has the list of names and aliases. 
Of the 100 volunteers, 33 actively left diaries throughout the research period. 67 participants dropped out within the first 30 days. Post-dropout interviews and Human Resources data showed this to have been primarily due to a national holiday in China. Mid-Autumn Festival is a week when some workers will go to their hometowns. Of the 67 who dropped out, 58 did not return to that factory after the break, either changing jobs or not returning to its location. The nine other people who left the study said they were not finding the diary experience rewarding, a few saying they felt uncomfortable talking about their feelings daily. This suggests that the barriers to diary research in the factory were more logistical than cultural. The 33 active diarists continued to report to their diaries throughout the holiday period for the sake of consistency. Despite a higher-thanexpected dropout rate, the large volume of initial interest meant the information collected was still considerable: the research participants left a total of 1,499 diary entries during the period of study.

\subsection{Data Analysis}

The data was analysed using a grounded approach (Glaser and Strauss, 1967). First, the entries were coded using open coding (Strauss and Corbin, 2008). The codes were then grouped to form a data structure comprising first-order concepts, second-order themes and a third level of aggregate dimensions (Gioia et al., 2013). There was a relatively large number of first-order concepts, reflecting the diverse range of topics and emotions discussed in the diaries. $40 \%$ of the first-order concepts related to day-to-day experiences for the diarists, such as what the workers ate for lunch or the weather. While this allows for a fascinating insight into daily life for a Chinese migrant factory worker, the focus of this article is the $60 \%$ of concepts related to the workplace. This is not because the other subject categories are unimportant; rather, it is because supervisors can do very little to influence workers' personal lives, while there may be concrete steps they could take within the workplace to improve well-being. The findings related to work are therefore explored below.

\section{Findings}

The data produced several new findings, presented below as follows. First is an overview of the different types of well-being reported by the workers in their work and their lives. Second, the article analyses the factors relating to workplace well-being from three points of view: the workers' aspirations and eudaimonic well-being in the long and short terms; their experiences of factory operational problems impacting their well-being; and relationships in the factory with implications for their social well-being. The section concludes with a summary of the findings.

\subsection{Hedonic, eudaimonic and social well-being in the factory}

The diaries provide a broad picture of the factors involved in well-being, including hedonic, eudaimonic and social aspects of both life and work. Examples of the subjects diarists speak about in each of these categories are shown in Figure 2.

\section{Figure 2: Types of well-being described in the diaries}

[Insert Figure 2 here] 
It is clear that many of the subjects that influence workers' well-being are unrelated to work. Relationships with family and friends and overall health play important roles in how workers feel. There are positive and negative sentiments in each of the subject categories: feelings about the different subjects are not uniformly positive or negative.

Despite the breadth of content of the diary entries, $60 \%$ of the first-order concepts are directly related to the workplace. The full data structure for the analysis of diary entries about the workplace is shown in Figure 3.

Figure 3: Data structure

[Insert Figure 3 here]

\subsection{Sources of motivation for workers}

Many of the diaries include comments about the worker's motivation to have a better life. Workers are focused on the ways in which their long-term aspirations can improve their own well-being and that of those around them - particularly family members. These often long-term goals shape the way in which the diarists think about their work. For example:

"I want to open a small restaurant selling Sichuan-style hot and sour noodles. I am inspired to work hard by this goal."

Diarists also connect these long-term goals to the short-term conditions they face in the factory:

"I want to save money for a car and driving license, so that I can live and work near my children and parents as a taxi-driver. I never meet my daily targets in the factory though! I will never achieve my life's dream (sad emoji)."

This suggests that eudaimonic well-being is important to the diarists, and that they take an instrumental view of their work at the factory as a means to achieving their goals. The goals mentioned include: building a house for their family; putting children through school; continuing their own education; and setting up their own business. Some diarists also describe shorter-term eudaimonic well-being arising from training or development in the factory.

"For me, today, I've come into a new field and been asked to learn some new things. So I'm a little nervous, afraid of making mistakes, but the prospect of learning new things also gives me energy."

In the short term, the diarists are focused on two different types of well-being: hedonic well-being, which they associate with compensation; and social wellbeing, associated with their relationships with colleagues and managers in the factory.

These social relationships can be positive or negative. Figure 3, above, shows that feeling appreciated by others can contribute to well-being. One diarist comments:

"Praised by the boss! I now wish to do even better, and will strive to rise to the position of director."

Positive team relationships are also motivating. At the end of a good day, one diarists says: 
"The employees are like a family. We all look out for each other. We set out to work in a good mood every day."

Other diaries suggest that workers do not start every day in a good mood, and there are several descriptions of unsatisfactory interactions with co-workers. One unexpected effect of this research method is that the workers started to see their diaries as a type of relationship, and benefitted from the opportunity to talk about their experiences knowing that someone would listen. This suggests that social contact is a particularly important facet of well-being, particularly for migrant workers who are separated from their families.

Workers are not only motivated by the camaraderie of team-work. They are very focused on compensation as an enabler of their longer-term goals. The factory where this research was conducted does pay its workers promptly, and they appreciate this. However, pay is calculated based on production targets, and there were many diary entries about operational problems leading to missed targets. These fell broadly into two groups: issues about the production system and problems leading to re-work.

\subsection{Operational problems in the factory}

The diarists report a range of operational problems including: machine breakdowns; engineers not coming to fix machines; raw materials arriving late or with defects; and process bottlenecks leaving workers standing idle. These can all be attributed to poor factory management. The workers show an understanding of the systemic impacts of these problems:

"Today, in the last hour of the evening overtime shift, the machine suddenly broke down and it couldn't be repaired properly. It was still not working when we finished, and a lot of goods have piled up. I hope he can repair it soon. I don't know whether it will be repaired tomorrow morning or not. If not, it will be a miserable day. This may impact other workers on the same line ... This makes me feel dispirited."

These problems also lead to some levels of overtime, a phenomenon that has prompted concern in the press in recent years. While overtime is paid, and therefore sometimes welcome, some diarists also report high levels of fatigue:

"We are very busy every day. I really want to get off work very much. I'm so tired."

This is obviously a barrier to their physical, hedonic well-being.

Frequent re-working of products is another source of frustration reported in the diaries.

"Today at work the supervisor held a meeting to tell us that the handbags we are making need more reworking. Most of the flaws are minor. Is it that people are making mistakes because the shifts are so long? Many workers think they are familiar with the bags, so they work ruthlessly and never think there will be defects that need rework."

The rework is caused by the lack of any pre-emptive quality management process in the factory. Training is inconsistent or absent, so workers do not always know how to make the products, or have not had time to practice sufficiently. As one diarist says: 
“My manager doesn't tell us what we need to do properly. When we do the work wrong, he is upset. I sometimes wonder if he understands himself what we should be doing."

This leads to errors, which are compounded by time pressure or other sources of stress such as operational problems. Rework and operational problems are both resulting in workers having to work harder to meet their targets, which they find demotivating.

\subsection{Working relationships}

While operational problems and reworking can both be attributed to poor operational factory management, the diaries also reveal poor working relationships with managers. In particular, diarists complain about being 'scolded' or shouted at. Some also report unfair treatment, such as favouritism by managers.

"This morning I was scolded by my line leader. He treats us all very differently.

He's nice to the workers he knows well and very impatient with everyone else."

In a context where it is clear that relationships and social contact matter to wellbeing, this type of behaviour can be very detrimental. It not only leads to a loss of a worker's own self-worth, but can also lead them to resent and devalue colleagues.

Diarists air several complaints about co-workers, which broadly fall into three categories. In several diary entries, people blame others - or express worries about being blamed - for production-line delays. Delays are felt keenly as they impact compensation. There is also some resentment arising from the preferential treatment they see some managers show to specific individuals, particularly when this limits opportunities for others:

"I was told that I could learn stitching, but the factory didn't fulfill this promise so I'm still only allowed to do odd, random tasks. I also get yelled at from time to time."

Finally, an undercurrent of the social problems that tend to arise when people live and work in close proximity is manifest in some diaries as complaints about gossip, dormitory noise or interactions such as borrowing money.

\subsection{Summary of findings}

Analysis of the diaries shows that a complex web of factors - hedonic, eudaimonic and social - influence the well-being of Chinese migrant factory workers. These are not independent: operational factors influence productivity (and therefore compensation) which can also impact relationships with colleagues and supervisors. There are positive aspects to life in the factory: compensation, the opportunity to develop and learn, and feeling appreciated through recognition by supervisors and colleagues. It is clear that the matters important to factory workers - the ability to progress toward their long-term vision for the future through compensation and learning, and the quality of their relationships with co-workers and supervisors - are not the factors made visible to brands by factory audits.

\section{Discussion}

\subsection{Theoretical implications}


This complex picture suggests that both narratives about the Chinese migrant factory-worker, as either someone acting with agency or a victim of exploitation, are over-simplified. The workers in this study are very motivated by the prospect of improving conditions for themselves and their families, but frustrated in this ambition not by the physical conditions in the factory - which are barely mentioned in the diaries - but by social and operational issues. To some extent this is because the factory environment for the research setting was acceptably safe. However, it also suggests that conventional methods for assessing workplace well-being, such as surveys focused primarily on hedonic factors or on job satisfaction, have both methodological and theoretical limitations in this setting. Assessments of 'job satisfaction' typically exclude frustration, which has only recently been identified as distinct from low satisfaction (Longo et al., 2016), yet feelings of frustration appear regularly in these diaries.

By contrast with conventional models of job satisfaction, the PsyCap model does address some of the aspects of well-being discussed in the diaries. While all components of the PsyCap model - hope, optimism, self-efficacy and resilience matter, two elements appear most important to our diarists. First, they speak often about their hopes for the future, which are clearly motivational for them. Second, their feelings of self-efficacy were noticeably impacted by the social and operational conditions in the factory. Self-efficacy is defined as "how well one can execute courses of action required to deal with prospective situations" (Bandura, 2012; Stajkovic and Luthans, 1998). The diaries suggest that workers' feelings of self-efficacy are undermined, first by their inability to address the operational difficulties in the factory that in turn drive rework and inefficiencies, and second by their treatment, and particularly scolding, by line supervisors and managers.

This confirms the observation that worker well-being has an important relational component, and that workplace practices can be influential in improving worker affect. Chinese society has historically emphasised social interests, collective action and shared responsibility (Chen et al., 2015). Pun (2005) quotes a worker saying about her experience of factory work: "Every day I would be worn out, all my energy gone. But I felt satisfied there. I had dozens of relatives and friends, we chatted a lot and helped each other." The current study reinforces this focus among factory workers on their need for positive relationships in the workplace as well as with family and friends.

These needs, for self-efficacy and for relatedness, have deep psychological roots. Deci and Ryan (2000) identify autonomy (the ability to act voluntarily and to have control over a situation), relatedness (ability to form human connections) and competence (ability to feel effective in achieving a goal) as basic psychological needs, fundamental to human thriving. It appears that their framework is not culturally-specific, and it has been successfully tested in China (Chen et al., 2014). Evidence from the diaries suggests that these basic psychological needs underpin the hope and efficacy elements of the PsyCap framework, and that the frustration of these needs leads to a loss of well-being. Thus, two elements of PsyCap, hope and self-efficacy, as underpinned in basic psychological need theory by autonomy, relatedness and competence, are here identified as important to the well-being of migrant factory-workers in China. However, the problem that motivated this paper remains: how can brands 
ensure the well-being of the factory-workers in their supply chains? Psychological states are, by their nature, not visible, yet the main method for assessing factory conditions - audit - focuses entirely on aspects that can be seen. To resolve this problem, research needs to identify the visible practices that can create an environment that allows PsyCap to flourish.

\subsection{Practical implications}

While previous studies using PsyCap have suggested that self-efficacy can be improved by training, relationships or encouragement and support from managers (Du et al., 2015; Rego et al., 2019) this study suggests that it can also be improved by creating a more efficient operating environment, in which workers are not frustrated in their goals by systemic failures. It can therefore be addressed by working to resolve the operational problems in factories and to improve HR systems to support, for example, supervisor behaviour and learning opportunities. These interventions have three potential benefits: first, they address the underlying barriers to well-being by reducing frustration; second, they have the potential to improve overall factory performance; and third, they may be visible to auditors.

Figure 4, below, shows how interventions at the factory line level (for example, providing training for supervisors and workers) can lead to fewer of the incidents associated with workers' dissatisfaction, and stronger feelings of personal development. This, in turn, creates stronger self-efficacy, which improves psychological capital. This is, of course, beneficial for moral reasons, but previous studies have also suggested tangible business benefits from these interventions, including reduced turnover rates and increased productivity (Luthans et al., 2008; Karatepe and Karadas, 2014; Park et al., 2016; Adler et al., 2017).

Figure 4. Potential impact, via PsyCap, of interventions on worker well-being [Insert Figure 4 here]

The proposed interventions are, at this stage, untested, while the proposal is predicated on previous studies conducted in different contexts. However, adding questions to audits to focus attention on the provision of training and on operational efficiency might improve factory performance, and so reduce the frustration experienced by workers.

\section{Conclusion}

This is the first study to use longitudinal digital diary methods in a factory setting. It highlights a gap in the way in which worker well-being is audited by Western brands sourcing goods from China. It makes three main contributions to the literature on psychological capital as a source of well-being. First, it demonstrates that two elements of the PsyCap model - self-efficacy and hope play an important role in eudaimonic well-being for Chinese factory workers. Second, while previous studies have suggested that self-efficacy can be improved by interpersonal interventions such as training or encouragement and support from managers, this study suggests that it can also be improved by reducing the frustration arising from frequent practical problems in the factories. Third, it proposes a theoretical model illustrating how selected interventions can 
improve well-being, and potentially performance, through improving selfefficacy. The study is not without limitations. It is on a relatively small scale, and was undertaken to identify the factors that Chinese factory workers in particular find important to their well-being.

One of the main findings - that workers value personal development, and are frustrated by inefficient factory operations - can be further developed in two ways. First, there are opportunities to develop more robust methods for using self-efficacy as a measure of well-being in factories. Second, this article proposes testing action-learning programmes in factories to see which interventions can most effectively improve well-being and productivity. Furthermore, the method used in this study may also be applicable in other settings involving people who are otherwise difficult to reach, are under-represented in research or have limited voice.

As well as these implications for further research, the study has implications for practice. It is becoming increasingly important for Chinese businesses to refocus from technological development and financial capital onto human resources (Luthans et al., 2008). The mobility of the contemporary Chinese worker, coupled with a willingness demonstrated by the latest generations to repeatedly switch jobs (Pun and Lu, 2010), poses challenges for the employer/employee contract and requires businesses to invest in workers to retain them: "Simply competing on the basis of low-cost labour is no longer sufficient in a China that is now in the mainstream of the global economy with increasing wages and competition for talent" (Luthans et al., 2008; Warner, 2013). China's continued growth and competitive advantage hinges on worker training and an updated understanding of human resources management (Luthans et al., 2008). This, coupled with increasing demands from Western customers that companies pay attention to employee welfare, suggests that there is a real need for a better way to audit factories which can direct attention to the factors that matter for workers. 


\section{References}

Adler, P., Brown, D., Dehejia, R., Domat, G. and Robertson, R. (2017), "Do Factory Managers Know What Workers Want? Manager-Worker Information Asymmetries and Pareto Optimal Human Resource Management Policies", Asian Development Review, Vol. 34 No. 1, pp. 65-87.

Alaszewski, A. (2006), Using diaries for social research, 1st edn., SAGE, Thousand Oaks, CA., London.

Andersen, M. and Skjoett-Larsen, T. (2009), “Corporate social responsibility in global supply chains”, Supply Chain Management: An International Journal, Vol. 14 No. 2, pp. 75-86.

Anner, M. (2012), “Corporate Social Responsibility and Freedom of Association Rights: The Precarious Quest for Legitimacy and Control in Global Supply Chains", Politics and Society, Vol. 40 No. 4, pp. 609-644.

Badran, M.A. and Youssef-Morgan, C.M. (2015), "Psychological capital and job satisfaction in Egypt", Journal of Managerial Psychology, Vol. 30 No. 3, pp. 354-370.

Bandura, A. (2012), "On the Functional Properties of Perceived Self-Efficacy Revisited", Journal of Management, Vol. 38 No.1, pp. 9-44.

Birdi, K., Clegg, C., Patterson, M., Robinson, A., Stride, C.B., Wall, T.D. and Wood, S.J. (2008), "The Impact of Human Resource and Operational Management Practices on Company Productivity: a Longitudinal Study", Personnel Psychology, Vol. 61 No. 3, pp. 467-501.

Capasso, R., Zurlo, M.C. and Smith, A.P. (2018), "Stress in Factory Workers in Italy: An Application of the Ethnicity and Work-related Stress Model in Moroccan Factory Workers", Psychology and Developing Societies, Vol. 30 No. 2, pp. 199-233.

Carter, C.R. and Rogers, D.S. (2008), "A framework of sustainable supply chain management: moving toward new theory", International Journal of Physical Distribution and Logistics Management, Vol. 38 No. 5, pp. 360-387.

Chan, A. (2001), "Globalization, the Social Clause, and China's Workers", Chinese Economy, Vol. 34 No. 6, pp. 12-31.

Chan, A. (2017), "The Resistance of Walmart Workers in China: A Missed Opportunity", Disturbances in Heaven, ANU Press, Acton ACT, Australia.

Chan, J. (2013), "A suicide survivor: the life of a Chinese worker", New Technology, Work and Employment, Vol. 28 No. 2, pp. 84-99.

Chen, J., Wang, L. and Tang, N. (2016), "Half The Sky: The Moderating Role of Cultural Collectivism in Job Turnover Among Chinese Female Workers", Journal of Business Ethics, Vol. 133 No. 3, pp. 487-498.

Cottini, E., Kato, T., Westergaard-Nielsen, N. and Forschungsinstitut zur Zukunft der Arbeit (2011), "Adverse workplace conditions, high-involvement work practices and labor turnover: Evidence from Danish linked employer-employee data", Labour Economics, Vol. 18 No. 6, pp. 872-880. Cruz, J.M. (2013), "Mitigating global supply chain risk through corporate social responsibility", International Journal of Production Research, Vol. 13 No. 51, pp. 3995-4010.

Deci, E.L and Ryan, R.M. (2000), "The 'what' and 'why' of goal pursuits: Human needs and the selfdetermination of behavior", Psychological Inquiry, Vol. 11, pp. 227-268.

Diener, E. (2000), 'Subjective well-being', American Psychologist, Vol. 55, pp. 34-43.

Dutton, J.E. (2003), "Fostering High-Quality Connections", Stanford Social Innovation Review, Vol. 1 No. 3, pp. 54-57.

Du, H., Li, X., Lin, D. and Tam C.C. (2015), "Collectivistic Orientation, Acculturative Stress, Cultural Self-Efficacy, and Depression: A Longitundinal Study Among Chinese Internal Migrants", Community Mental Health Journal, Vol. 51, pp. 239-248.

Earley, P.C. (1994), "Self or Group? Cultural Effects of Training on Self-Efficacy and Performance", Administrative Science Quarterly, Vol. 39 No. 1, pp. 89-117.

Egels-Zandén, N. (2014), "Revisiting Supplier Compliance with MNC Codes of Conduct: Recoupling Policy and Practice at Chinese Toy Suppliers", Journal of Business Ethics, Vol. 119 No. 1, pp. 59-75.

Egels-Zandén, N., Hulthén, K. and Wulff, G. (2015), "Trade-offs in supply chain transparency: the case of Nudie Jeans Co", Journal of Cleaner Production, Vol. 107, pp. 95-104. 
Fansuo, A. and Bramble, T. (2017), "Silence as a survival strategy: will the silent be worse off? A study of Chinese migrant workers in Guangdong", The International Journal of Human Resource Management, Vol. 29 No. 5, pp. 915-940, available at: http://doi.org/10.1080/09585192.2017.1328609

Fisher, C. (2014), “Conceptualising and Measuring Well-being at Work”, Work and Wellbeing: $A$ complete reference guide, Eds. Chen, P.Y and Cooper, C., John Wiley and Sons.

Franceschini, I. (2020), "At the Roots of Labour Activism: Chinese and Cambodian Garment Workers in Comparative Perspective", Journal of Contemporary Asia, Vol. 50 No. 1, pp. 144-167.

Freise, M. and Seuring, S. (2015), "Social and environmental risk management in supply chains: A survey in the clothing industry", Logistics Research, Vol. 8, pp. 1-12.

Frese, M., Kring, W., Soose, A. and Zempel, J. (1996), "Personal Initiative at Work: Differences between East and West Germany", The Academy of Management Journal, Vol. 39 No. 1, pp. 37-63. Frese, M. (2008), "The Word Is Out: We Need an Active Performance Concept for Modern Workplaces", Industrial and Organizational Psychology, Vol. 1 No. 1, pp. 67-69.

Gao, J. and Bansal, T. (2013), "Instrumental and Integrative Logics" in Business Sustainability Journal of Business Ethics, Vol. 112 No. 2, available at: http://doi.org/10.1007/s10551-012-12452

Gallagher, M.W., Lopez, S.J. and Preacher, K.J. (2009), "The hierarchical structure of well-being", Journal of Personality, Vol. 77, pp. 1025-1050.

Gioia, D.A., Corley, K.G. and Hamilton, A.L. (2013), "Seeking qualitative rigor in inductive research: notes on the Gioia methodology", Organizational Research Methods, Vol. 16 No. 1, pp. 15-31.

Glaser, B.G. and Strauss, A.L. (1967), The discovery of grounded theory: strategies for qualitative research, Aldine Transaction, New Brunswick, NJ.

Glendon, L. (2013), "Winners and losers in the complex web of global supply chains", Journal of Business Continuity and Emergency Planning, Vol. 6 No. 4, pp. 322-328.

Görg, H., Hanley, A. and Seric, A. (2018), "Corporate Social Responsibility in Global Supply Chains: Deeds Not Words", Sustainability, Vol. 10 No. 10, pp. 3675.

Grayson, D. and Nelson, J. (2013), Corporate Responsibility Coalitions: the Past, Present, and Future of Alliances for Sustainable Capitalism, 1st edn., Stanford University Press, Palo Alto.

Gunawardana, S.J. (2014), "Reframing employee voice: a case study in Sri Lanka's export processing zones", Work, Employment and Society, Vol. 28 No. 3, pp. 452-468.

Hackman, J.R. and Oldham, G.R. (1976), "Motivation through the design of work: test of a theory", Organizational Behavior and Human Performance, Vol. 16 No. 2, pp. 250-279.

Hassler, R., Bonning, M., Demuth, F., Hellwig, A., Niewierra, D. and Scherzinger, T. (2017), Global Transformation Processes - Are Companies Already on the Right Track? available at: http://www.oekom-research.com/homepage/english/oekom_cr_review_E_2017.pdf (accessed: April 24, 2018).

Hsu, M. and Chen, F.H. (2015), "The Cross-Level Mediating Effect of Psychological Capital on the Organizational Innovation Climate-Employee Innovative Behavior Relationship", The Journal of Creative Behavior, Vol. 51 No. 2, pp. 128-139.

Jacka, T. (2014), Rural Women in Urban China: Gender, Migration, and Social Change, Taylor \& Francis, Hoboken.

Joo, B., Park, J.G. and Lim, T. (2016), "Structural determinants of psychological well-being for knowledge workers in South Korea", Personnel Review, Vol. 45 No. 5, pp. 1069-1086.

Joo, B. and Lee, I. (2017), "Workplace happiness: work engagement, career satisfaction, and subjective well-being", Evidence-Based HRM, Vol. 5 No. 2, pp. 206.

Judge, T.A., Thoresen, C.J., Bono, J.E. and Patton, G.K. (2001), "The job satisfaction-job performance relationship: A qualitative and quantitative review", Psychological Bulletin, Vol. 127 No. 3, pp. 376-407.

Karatepe, O.M. and Karadas, G. (2014), "The effect of psychological capital on conflicts in the work-family interface, turnover and absence intentions", International Journal of Hospitality Management, Vol. 43, pp. 132-143. 
Kim, J. (2015), "A Bumpy Road to Cities: Analysis of the Obstacles and Limits of China's New Urbanization", Pacific Focus, Vol. 30 No. 3, pp. 372-388.

Köksal, D., Strähle, J., Müller, M. and Freise, M. (2017), "Social Sustainable Supply Chain Management in the Textile and Apparel Industry-A Literature Review", Sustainability, Vol 9 No. 1 , pp. 100.

Lamb, S. and Kwok, K.C.S. (2016), “A longitudinal investigation of work environment stressors on the performance and wellbeing of office workers", Applied Ergonomics, Vol. 52, pp. 104-111.

Locke, R.M., Qin, F. and Brause, A. (2007), "Does Monitoring Improve Labor Standards? Lessons from Nike", Industrial and Labor Relations Review, Vol. 61 No. 1, pp. 3-31.

Locke, R.M. (2013), The Promise and limits of private power: promoting labor standards in a global economy, Cambridge University Press, Cambridge, New York.

Longo, Y., Gunz, A., Curtis, G.J. and Farsides, T. (2016), “Measuring Need Satisfaction and Frustration in Educational and Work Contexts: The Need Satisfaction and Frustration Scale (NSFS)", Journal of Happiness Studies, Vol. 17 No. 1, pp. 295-317, avaialble at: https://doi.org/10.1007/s10902-014-9595-3

Luthans, F., Avolio, B.J., Walumbwa, F.O. and Li, W. (2005), "The Psychological Capital of Chinese Workers: Exploring the Relationship with Performance", Management and Organization Review, Vol. 1 No. 2, pp. 249-271.

Luthans, F., Norman, S. and Hughes, L. (2006), "Authentic Leadership", Inspiring Leaders, Routledge, Taylor \& Francis, London, pp. 84-104.

Luthans, F., Avolio, B.J., Avey, J.B. and Norman, S.M. (2007), "Positive psychological capital: Measurement and relationship with performance and satisfaction", Personnel Psychology, Vol. 60, pp. 541-572.

Luthans, F., Avey, J.B., Clapp-Smith, R. and Li, W. (2008), "More evidence on the value of Chinese workers' psychological capital: A potentially unlimited competitive resource?", The International Journal of Human Resource Management, Vol. 19 No. 5, pp. 818-827.

Luthans, F., Avey, J., Avolio, B. and Peterson, S. (2010), "The Development and Resulting Performance Impact of Positive Psychological Capital", Human Resource Development Quarterly, Vol. 21 No. 1, pp. 41-67.

Luthans, F., Youssef, C.M. and Rawski, S.L. (2011), "A Tale of Two Paradigms: The Impact of Psychological Capital and Reinforcing Feedback on Problem Solving and Innovation", Journal of Organizational Behavior Management, Vol. 31 No. 4, pp. 333-350.

Luthans, F. and Youssef-Morgan, C.M. (2017), "Psychological Capital: An Evidence-Based Positive Approach", Annual Review of Organizational Psychology and Organizational Behavior, Vol. 4 No. 1, pp. 339-366.

Ma, L. and Jacobs, F. (2010), "Poor But Not Powerless: Women Workers in Production Chain Factories in China", Journal of Adolescent Research, Vol. 25 No. 6, pp. 807-838.

Mazzetti, G., Guglielmi, D., Chiesa R. and Mariani, M.C. (2016), "Happy employees in a resourceful workplace: just a direct relationship? A study on the mediational role of psychological capital", Career Development International, Vol. 21, No. 7, pp. 682-696.

Meixell, M.J. and Luoma, P. (2015), "Stakeholder pressure in sustainable supply chain management: A systematic review", International Journal of Physical Distribution \& Logistics Management, Vol. 45 No. 1/2, pp. 69-89.

Nel, P. and Kotzé, M. (2017), "The influence of psychological resources on mineworkers' levels of burnout in a remote and isolated mining town in South Africa", The Extractive Industries and Society, Vol. 4 No. 4, pp. 885-892.

Newbert, S.L. (2007), "Empirical Research on the Resource-based View of the Firm: An Assessment and Suggestions for Future Research", Strategic Management Journal, Vol. 28 No. 2 , pp. 121-146.

Newman, A., Ucbasaran, D., Zhu, F. and Hirst, G. (2014), "Psychological capital: A review and synthesis", Journal of Organizational Behavior, Vol. 35 No. 1, pp. 120-138.

Ngan, R. and Ma, S.K. (2012), "Mobile Phone and the Empowerment of Migrant Workers in Job Searches in China's Pearl River Delta", New Connectivities in China, Springer, NY, pp. 105-119.

Niforou, C. (2015), "Labour Leverage in Global Value Chains: The Role of Interdependencies and Multi-level Dynamics", Journal of Business Ethics, Vol. 130 No. 2, pp. 301-311. 
Nolzen, N. (2018), "The concept of psychological capital: a comprehensive review", Management Review Quarterly, Vol. 68 No. 3, pp. 237-277.

O'Rourke, D. (2003), "Outsourcing Regulation: Analyzing Nongovernmental Systems of Labor Standards and Monitoring", Policy Studies Journal, Vol. 31 No. 1, pp. 1-29.

Park, J.H., Newman, A., Zhang, L., Wu, C. and Hooke, A. (2016), "Mentoring functions and turnover intention: the mediating role of perceived organizational support", The International Journal of Human Resource Management, Vol. 11, pp. 1173-1191.

Parker, S.K., Wall, T.D. and Cordery, J.L. (2001), "Future work design research and practice: Towards an elaborated model of work design", Journal of Occupational and Organizational Psychology, Vol. 74 No. 4, pp. 413-440.

Patterson, A. (2005), "Processes, relationships, settings, products and consumers: the case for qualitative diary research", Qualitative Market Research: An International Journal, Vol. 8 No. 2, pp. 142-156.

Peng, Y. and Choi, S.Y.P. (2013), "Technologies of power and resistance: Mobile phone use among factory migrant workers in south China", The China Quarterly, Vol. 215, pp. 553-571, available at: http://doi.org/10.1017/S0305741013000738

Peterson, S.J., Luthans, F., Avolio, B.J., Walumbwa, F.O. and Zhang, Z. (2011), "Psychological Capital and Employee Performance: a Latent Growth Modelling Approach", Personnel Psychology, Vol. 64 No. 2, pp. 427-450.

Pouramini Z. and Fayyazi, M. (2015), "The relationship between positive organizational behavior with job satisfaction, organizational citizenship behavior, and employee engagement", International Business Review, Vol. 8 No. 9, pp. 57-66.

Pratt, M.G. and Ashforth, B.E. (2003), "Fostering Meaningfulness in Working and at Work", Positive Organizational Scholarship: Foundations of a New Discipline, Barrett-Koehler, pp. 309327.

Pun, N. (2005), Made in China: women factory workers in a global workplace, Duke University Press, Hong Kong, Durham [NC].

Pun, N and Lu, H. (2010), "Unfinished Proletarianization: Self, Anger, and Class Action among the Second Generation of Peasant-Workers in Present-Day China", Modern China, Vol. 36 No. 5, pp. 493-519.

Qadeer F. and Jaffery, H. (2014), "Mediation of psychological capital between organizational climate and organizational citizenship behavior", Pakistan Journal of Commerce and Social Science, Vol. 8 No. 2, pp. 453-470.

Rego, A., Owens, B., Yam, K.C., Bluhm, D., Cunha, M.P., Silard, A., Martins, L.G.M., Simpson, A.V. and Liu. W. (2019), "Leader Humility and Team Performance: Exploring the Mediating Mechanisms of Team PsyCap and Task Allocation Effectiveness", Journal of Management, Vol. 45 No. 3, pp. 10091033.

Rivkin, W., Diestel, S. and Schmidt, K.H. (2018), "Which Daily Experiences Can Foster Well-Being at Work? A Diary Study on the Interplay Between Flow Experiences, Affective Commitment, and Self-Control Demands", Journal of Occupational Health Psychology, Vol. 23 No. 1, pp. 99-11.

Rogers, Z.S. (2016), It's Your Responsibility: The Impact of Supply Chain CSR Performance on Firm Value, Arizona State University.

Sanders, S.R., Cope, M.R. and Pulsipher, E.R. (2018), "Do Factory Audits Improve International Labor Standards? An Examination of Voluntary Corporate Labor Regulations in Global Production Networks", Social Sciences, Vol. 7 No. 6, pp. 84.

Sein, M.M., Howteerakul, N., Suwannapong, N. and Jirachewee, J. (2010), "Job Strain among Rubber-Glove-Factory Workers in Central Thailand", Industrial Health, Vol. 48 No. 4, pp. 503-510. Seligman, M.E.P. and Csikszentmihalyi, M. (2000), "Positive Psychology: An Introduction", American Psychologist, Vol. 55 No. 1, pp. 5-14.

Seuring, S. (2013), "A review of modeling approaches for sustainable supply chain management", Decision Support Systems, Vol 54 No. 4, pp. 1513-1520.

Seuring, S. and Müller, M. (2008), "From a literature review to a conceptual framework for sustainable supply chain management", Journal of Cleaner Production, Vol. 16 No. 15, pp. 16991710. 
Silvestre, B.S. (2015), "Sustainable supply chain management in emerging economies: Environmental turbulence, institutional voids and sustainability trajectories", International Journal of Production Economics, Vol. 167, pp. 156-169.

Siu, K. (2017), "Labor and Domination: Worker Control in a Chinese Factory", Politics and Society, Vol. 45 No. 4, pp. 533-557.

Snowden, M. (2015), "Use of diaries in research", Nursing Standard (Royal College of Nursing, Great Britain), Vol. 29 No. 44, pp. 36-41.

Snyder, C.R. and Lopez, S.J. (2007), Positive psychology: The scientific and practical explorations of human strengths, Sage Publications, Thousand Oaks, CA.

Stajkovic, A.D. and Luthans, F. (1998), "Self-efficacy and work-related performance: A meta-analysis", Psychological Bulletin, Vol. 124 No. 2, pp. 240.

Strauss, A. and Corbin, J. (2008), "Basics of Qualitative Research: Techniques and Procedures for Developing Grounded Theory", Basics of qualitative research: Grounded theory procedures and techniques, 3rd Edn., Sage, Los Angeles, London, available at:

https://doi.org/10.4135/9781452230153

Taylor, C. (2018), "'Nightmare' conditions at Chinese factories where Hasbro and Disney toys are made", CNBC Business News, 11 Dec, available at:

https://www.cnbc.com/2018/12/07/nightmare-at-chinese-factories-making-hasbro-anddisney-toys.html (accessed 24 April, 2020).

Taylor, I. and Taylor, A.F. (2003), The Assassin's Cloak: An Anthology of the World's Greatest Diarists, Canongate Books.

Unger, J. and Siu, K. (2019), "Chinese migrant factory workers across four decades: shifts in work conditions, urbanisation, and family strategies", Labor History, Vol. 60 No. 6, pp. 765-778.

Van der Bijl, J.J. and Shortridge-Baggett, L.M. (2002), "The theory and measurement of the selfefficacy construct", in Lentz, E.A. and Shortridge-Baggett, L.M. (eds.) Self-efficacy in nursing: Research and measurement perspectives, Springer, New York, pp. 9-28.

Vogel, D. (2010), "The Private Regulation of Global Corporate Conduct: Achievements and Limitations", Business and Society, Vol. 49 No. 1, pp. 68-87.

Warner, M. (2013), Human Resource Management 'with Chinese Characteristics': Facing the Challanges of Globalization, Routledge.

Weiss, H.M. and Brief, A.P. (2001), "Affect at work: an historical perspective", in Payne, R.L. and Cooper, C.L. (eds.), Emotions at Work: Theory, Research, and Application, Wiley, London.

Wright, P.M. and Nishii, L.H. (2006), "Strategic HRM and Organizational Behavior: Integrating Multiple Levels of Analysis", CAHRS Working Paper Series, 06-05.

Yang, C. and He, C. (2016), "Transformation of China's 'World Factory': Production Relocation and Export Evolution of the Electronics Firms", Tijdschrift Voor Economische en Sociale Geografie.

Zajak, S. (2017), "Channels for Workers' Voice in the Transnational Governance of Labour Rights?", Global Policy, Vol. 8 No. 4, pp. 530-539.

Zhu, X., Iles, P. and Shutt. J. (2011), "Employability, skills and talent management in Zhejiang Province", Journal of Chinese Entrepreneurship, Vol. 3 No. 1, pp. 24-35. 


\section{IJOPM Cover Letter}

\section{Dear Professor Blome}

Ref: IJOPM-06-2019-0492

Thank you for allowing us the opportunity to revise our article 'Capturing the psychological well-being of Chinese factory workers'. We found the feedback from the reviewers extremely constructive, and believe this process has considerably improved the work. This letter outlines the revisions we have made in response to that feedback. In it, we address four main topics: the theoretical framing; data analysis; discussion; and some broader editorial corrections.

Your first recommendation was to broaden our literature review beyond the supply chain management / operations management literature in order to more clearly frame our contribution to the study of well-being. In response, we have revised the theoretical sections extensively to include a review of theories of well-being and to clarify the relationship of this literature to Psychological Capital theory. This enabled us to clarify the need for the research, improve the logical flow of the argument, and narrow and focus the contribution of this paper.

Second, the second reviewer strongly encouraged us to revise our analytical approach and to review the data as qualitative rather than quantitative. We have therefore extensively revised the analysis and findings sections and used the Gioia method to structure the data. As suggested, we have introduced subheadings to clarify the structure of this section. While this involved extensive rewriting, we believe it makes the link between the literature, the data and the contribution much clearer and so strengthens the argument of the paper.

As a result of this reframing, we have also re-written the discussion section. One of your recommendations was to strengthen the theoretical discussion, to make the paper less 'pracademic'. Situating our findings in the context of the wellbeing literature has enabled us to develop the theoretical discussion more fully. We have also restructured this section and included sub-headings to distinguish the research implications from the practical implications of the work.

It is our view that these three major changes have significantly improved the overall flow and clarity of the paper while maintaining its distinctiveness and its fit with the aims and style of the IJOPM. We have also addressed a series of smaller but also important points raised by the reviewers. In particular we have: removed the original Figure 1 and some related comments on the supply chain literature; included more commentary on physical well-being, and in particular safety (the focus of previous work on factory workers' well-being); and made some revisions to the style of the paper to make it more congruent with that of the IJOPM.

We believe the suggested changes have significantly improved the quality of the manuscript and that it will be judged suitable for inclusion in your Special 
Edition. We very much appreciate the constructive feedback from you and the reviewers, and look forward to hearing your views on this latest version.

Best wishes. 


\begin{tabular}{|c|c|c|c|}
\hline & Hedonic well-being & Eudaimonic well-being & Social well-being \\
\hline $\begin{array}{l}\text { Life } \\
\text { well-being }\end{array}$ & $\begin{array}{l}\text { Positive affect } \\
\text { Negative affect } \\
\text { Life satisfaction }\end{array}$ & $\begin{array}{c}\text { Autonomy } \\
\text { Personal growth } \\
\text { Purpose in life } \\
\text { Self-acceptance }\end{array}$ & $\begin{array}{c}\text { Social acceptance } \\
\text { Social integration } \\
\text { Positive relations with } \\
\text { others }\end{array}$ \\
\hline \multirow[t]{2}{*}{$\begin{array}{l}\text { Well-being } \\
\text { at work }\end{array}$} & $\begin{array}{c}\text { Job satisfaction } \\
\text { Positive/negative affect } \\
\text { Organisational } \\
\text { commitment }\end{array}$ & $\begin{array}{l}\text { Job involvement } \\
\text { Work engagement } \\
\text { Meaning at work } \\
\text { Calling at work }\end{array}$ & \multirow[t]{2}{*}{$\begin{array}{l}\text { Relationships with } \\
\text { peers and leaders } \\
\text { Social support } \\
\text { Group cohesion }\end{array}$} \\
\hline & \multicolumn{2}{|c|}{$\begin{array}{c}\text { Flow } \\
\text { Intrinsic motivational states }\end{array}$} & \\
\hline
\end{tabular}

Figure 1: The drivers of well-being as seen in life and work 


\begin{tabular}{|c|c|c|c|}
\hline & Hedonic well-being & Eudaimonic well-being & Social well-being \\
\hline $\begin{array}{l}\text { Life well- } \\
\text { being }\end{array}$ & $\begin{array}{l}\text { Improved financial situation (pay debts, buy } \\
\text { house) } \\
\text { Health } \\
\text { Food (local food and healthy food) } \\
\text { Live in hometown }\end{array}$ & $\begin{array}{l}\text { Personal ambitions and aspirations - acquire } \\
\text { life skills, marriage, children, care for parents } \\
\text { Experiences - travel, food } \\
\text { Learning - go back to school }\end{array}$ & $\begin{array}{l}\text { Community in hometown } \\
\text { Family relationships } \\
\text { Romantic relationships } \\
\text { Friendship }\end{array}$ \\
\hline $\begin{array}{l}\text { Well-being at } \\
\text { work }\end{array}$ & $\begin{array}{l}\text { Reworking constantly - tasks too complex, } \\
\text { bad quality raw materials } \\
\text { Delays - machine breakdowns, slow } \\
\text { colleagues, raw materials late } \\
\text { Work environment stressful - shouting, } \\
\text { fighting }\end{array}$ & $\begin{array}{l}\text { Hard work and efforts at work are fruitless - } \\
\text { targets not met } \\
\text { Reduced sense of self-worth - development } \\
\text { opportunities (negative) } \\
\text { Short- and long-term aspirations not achieved } \\
\text { - no promotion or learning }\end{array}$ & $\begin{array}{l}\text { Relationships with co-workers (negative) } \\
\text { Relationships with leaders (negative) } \\
\text { No team spirit or camaraderie in factory }\end{array}$ \\
\hline
\end{tabular}

Figure 2: Types of well-being described in the diaries 


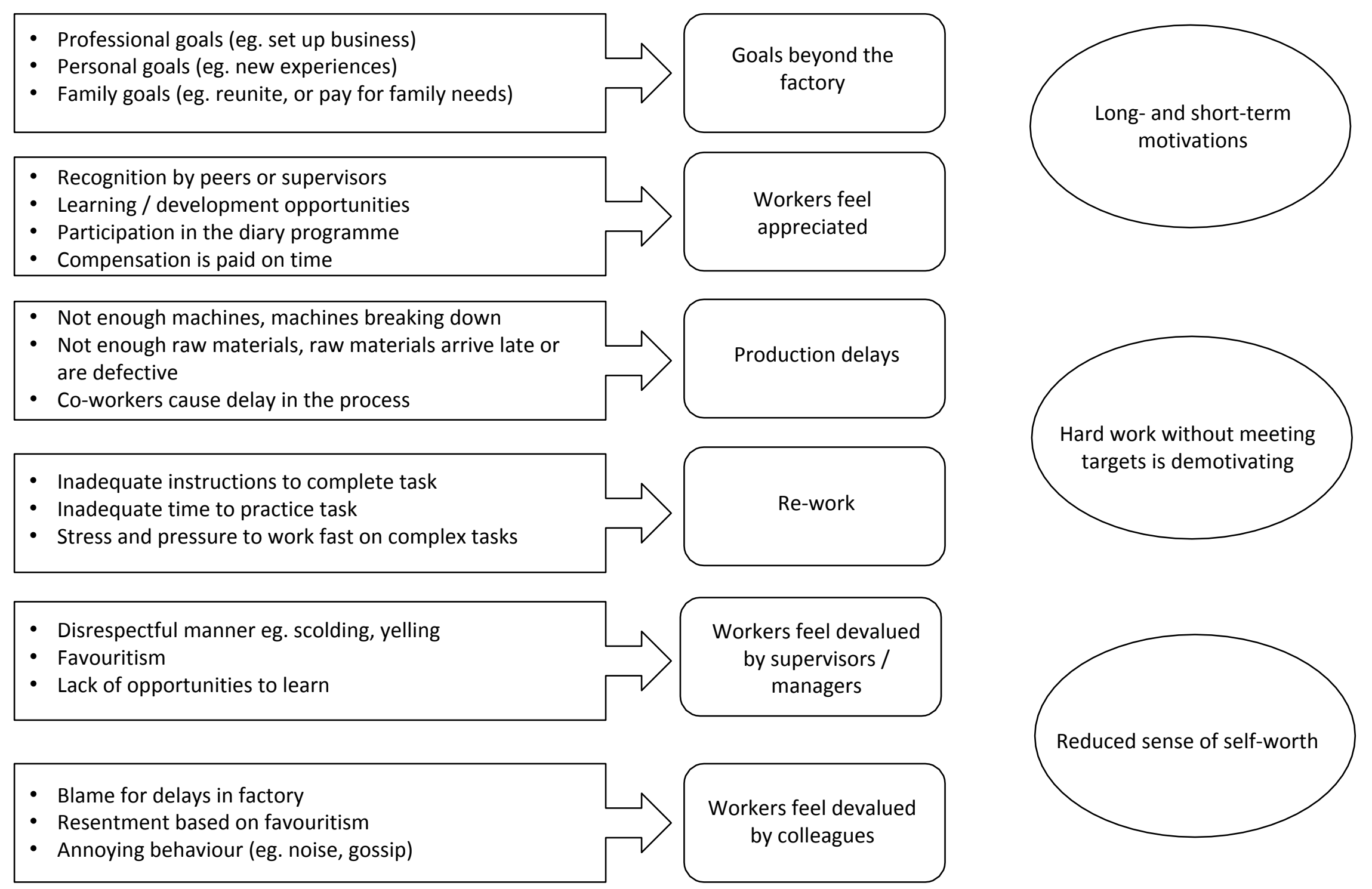

Figure 3: Data structure 
Fewer operational problems and less worker harassment

Training for managers (how to interact with staff and be effective and efficient) 15
15
16

17

18

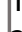

20

22

23

24
25

26

27

28

29

30

31

32

33

34

35

36

37

38

39

40

41

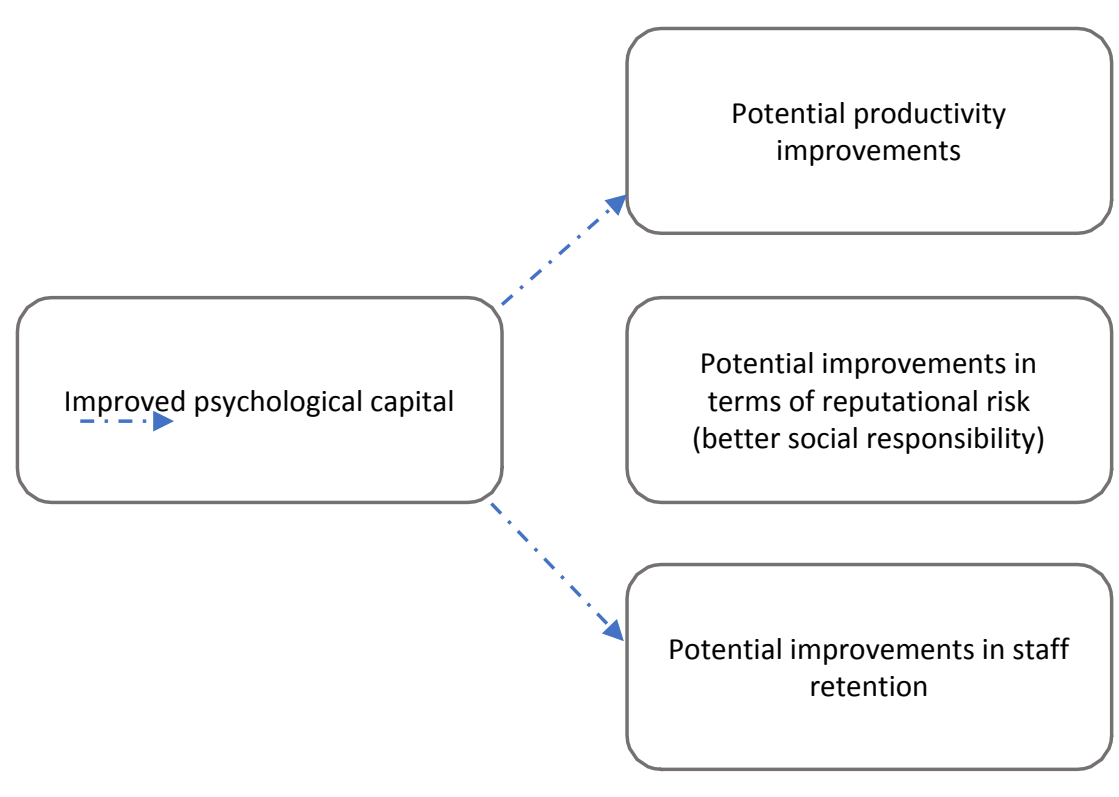

Figure 4. Potential impact, via PsyCap, of interventions on worker well-being 
Fewer operational problems and less worker harassment

Training for managers (how to interact with staff and be effective and efficient)

Training for workers on how to make the products

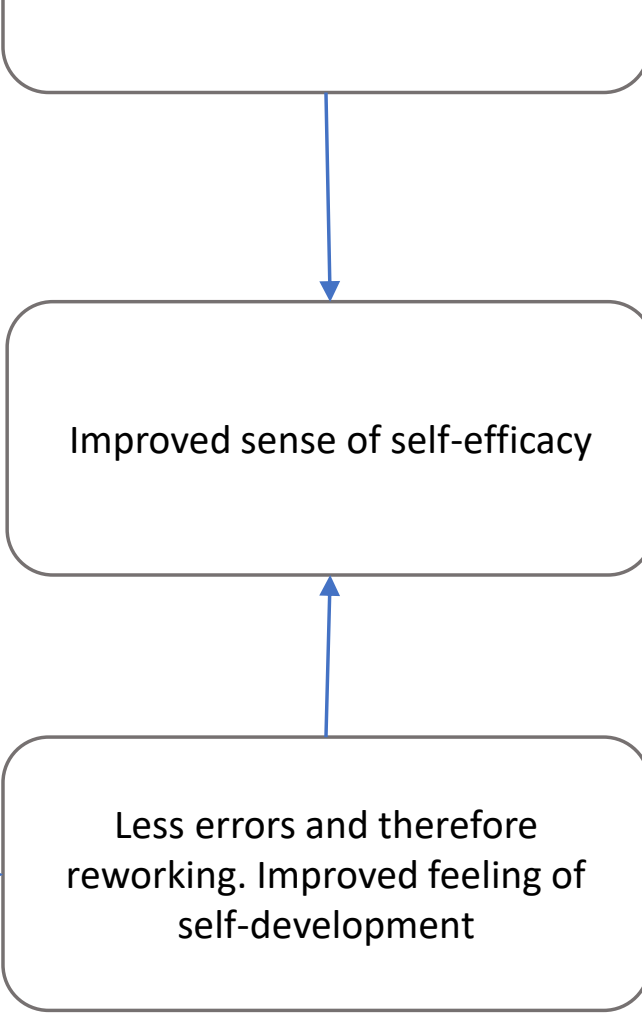

Potential productivity improvements
Potential improvements in terms

of reputational risk (better social

responsibility)
Potential improvements in staff retention

Figure 4. Potential impact, via PsyCap, of interventions on worker well-being 